\title{
EFEKTYWNOŚĆ W OCHRONIE ZDROWIA JAKO WYZWANIE DLA ZARZADZZANIA
}

DOI: $10.33141 /$ po.2020.05.04

\section{Ewa Raczyńska}

\section{Wprowadzenie}

$\mathrm{E}$ fektywność w jednostkach ochrony zdrowia jest zagadnieniem trudnym i nieczęsto analizowanym w literaturze. Główny nacisk kładziony jest na efektywność ekonomiczną (Głodziński, 2014, s. 159), co nie zawsze jest odpowiedzią na problemy praktyki gospodarczej. Współczesne pojęcie efektywności skupia się również na kwestiach organizacyjnych, technicznych, społecznych, środowiskowych i marketingowych (Głodziński, 2014, s. 156). Warto zwrócić przy tym uwagę, iż w ochronie zdrowia panuje duża turbulencja środowiska (Szymaniec-Mlicka, 2014, s. 634), a sam sektor jest silnie uzależniony od aktualnej polityki (Wielicka, 2014, s. 496). Nawet nomenklatura ulega zmianom, $\mathrm{z}$ tradycyjnego nazewnictwa służba zdrowia, na około dekadę temu, ochrona zdrowia i kolejno w ostatnich latach znów służba zdrowia (Sadowska, 2016). Ogrom zmian i brak stabilizacji nie służy sektorowi, co wyraźnie widać w wypowiedziach zarządzających podmiotami leczniczymi. Doniesienia o beznadziejnej
Przegląd Organizacji, Nr 5(964), 2020, s. 27-34

www.przegladorganizacji.pl

( ) Towarzystwo Naukowe Organizacji i Kierownictwa (TNOiK) kondycji publicznej służby zdrowia, gdzie szacuje się, że 90\% szpitali powiatowych przynosi straty (Nojszewska i in., 2019, s. 5) pozwala poddać w wątpliwość tezę, iż system działa efektywnie i efektywnie wykorzystuje zasoby. Otóż zasoby finansowe są jedynie częścią determinant efektywności (co przedstawi niniejszy artykuł). Ze względu na trudną sytuację finansową szpitali, gdy sztuką jest „wyjść na zero”, warto skupić się na pozostałych wymiarach efektywności i identyfikować obszary potencjalnej optymalizacji zwiększającej efektywność. Oszczędności w podmiotach leczniczych często są iluzoryczne (Paździor, Paździor, 2017, s. 60), a niewłaściwe decyzje mogą powodować szereg komplikacji w późniejszym terminie związanych z naruszeniem praw pacjenta, zagrożeniem jego bezpieczeństwa lub bezpieczeństwa personelu. Dodatkowo trudna sytuacja na rynku pracy związana z małą ilością personelu medycznego, w szczególności lekarzy, ale również pielęgniarek czy fizjoterapeutów, nakazuje wręcz 
podkreślenie wymiarów behawioralnych efektywności. Należy przy tym pamiętać, że ochrona zdrowia, zgodnie z Konstytucją (1997, art. 68), ma zapewnić dostęp do opieki zdrowotnej obywatelom, więc efektywność czasem musi ustąpić potrzebom społecznym, a alokacja zasobów powinna podlegać racjonalizacji i priorytetyzacji (Kolasa, 2012, s. 17).

Artykuł charakteryzuje się kompleksowym, holistycznym spojrzeniem na efektywność ochrony zdrowia. Eksplorowane będą kwestie związane $\mathrm{z}$ efektywnością na poziomie makro (system ochrony zdrowia) i mikro (podmioty gospodarcze). Ważną kwestią jest podkreślenie silnej zależności między systemem a jednostkami ochrony zdrowia (Nojszewska, 2011, s. 14). System ochrony zdrowia w literaturze nazywany bywa również systemem zdrowotnym, opieki medycznej czy opieki zdrowotnej. Definiowany jest jako spójna całość, której liczne i powiązane ze sobą części, dzięki wspólnym oddziaływaniom, wpływają na stan zdrowia ludności (Suchecka, 2010, s. 32). Natomiast sektor, zgodnie z założeniami Portera (Gierszewska, Romanowska, 2017, s. 71), należy rozumieć jako grupę przedsiębiorstw (podmiotów leczniczych) korzystających z tych samych zasobów i zaspokajających potrzeby zdrowotne tej samej grupy (populacji). Silne uregulowanie systemu i zasad działania jednostek ochrony zdrowia budujących system (w szczególności realizujących kontrakt z Narodowym Funduszem Zdrowia) wymusza holistyczne ujęcie tematu.

\section{Metoda badawcza}

C elem artykułu jest eksploracja i opis zjawiska efektywności w ochronie zdrowia. Metoda badawcza prezentowana $\mathrm{w}$ artykule to krytyczna analiza literatury przedmiotu. Analizowana pierwotnie literatura obejmowała bazę Google Scholar, BazEkon oraz ProQuest. Słowa kluczowe wyszukiwane $\mathrm{w}$ literaturze anglojęzycznej to między innymi: effectiveness, efficiently, effectively, health care, hospitals, clinic, efficacy, lean management, quality. Po zapoznaniu się w wybraną literaturą autorka postanowiła skupić się na pozycjach polskojęzycznych. Początkowo (w celu zapoznania się z tematyką) efektywność, ochrona zdrowia, efektywnie, służba zdrowia, kolejno (po pozyskaniu podstawowej bazy artykułów) skoncentrowała się na terminach efektywność organizacyjna, efektywność gospodarcza, efektywność finansowa, szpital, sektor publiczny, podmiot leczniczy, bariery, bariery efektywności, determinanty efektywności, następnie połączenia słów kluczowych efektywność, ochrona zdrowia z kategoriami słów związanymi z zzl, przywództwem, nowoczesnymi koncepcjami zarządzania (takimi jak np. lean management), jakością, integracją systemów. Przy tworzeniu artykułu wykorzystano prace obejmujące nauki o zarządzaniu i jakości oraz nauki o finansach i ekonomii. Autorka nie analizowała artykułów z zakresu nauk medycznych, zapoznała się jednak $z$ najlepiej cytowanymi (związanymi ściśle $\mathrm{z}$ tematyką) pracami $\mathrm{z}$ dyscypliny nauki o zdrowiu. Po analizie literatury anglo- i polskojęzycznej autorka w pracy nad artykułem skupiła się głównie na tekstach polskojęzycznych ze względu na specyfikę polskiej ochrony zdrowia wraz z jej uwarunkowaniami prawnymi i zarządzeniami prezesa NFZ, odmiennymi od anglosaskich systemów. Trudnością w wyborze literatury była mnogość pozycji dotyczących efektywności jako rezultatu, główny nacisk został zatem położony na najnowsze pozycje dotyczące efektywności, ochrony zdrowia, czynników wpływających na efektywność, pomiaru efektywności, a kolejno analiza została rozszerzona o kwestie związane z czynnikami wskazanymi w literaturze jako wpływające na efektywność. Autorka bazowała również na własnych doświadczeniach zawodowych, które można częściowo uznać jako obserwację uczestniczącą. Pytania badawcze, które postawiła autorka, to:

1. Jak definiować efektywność w sektorze ochrony zdrowia?

2. Jakie są bariery efektywności?

3. Jakie są determinanty efektywności w sektorze ochrony zdrowia?

Sformułowane zostaną również wnioski wynikające dla praktyki i nauki - potencjalne obszary badawcze oraz elementy doskonalenia.

\section{Efektywność i efektywność w sektorze ochrony zdrowia}

W literaturze wielokrotnie podkreślana jest trudność charakterystyki definicji efektywności dla sektora ochrony zdrowia. Każdy z interesariuszy systemu zrozumie efektywność inaczej (Paździor, Paździor, 2017, s. 55), dlatego tak ważna jest kwestia zdefiniowania tej kategorii w kontekście funkcjonowania sektora ochrony zdrowia. Istotne jest wskazanie również często powielanego błędu, który polega na mieszaniu ze sobą pojęć efektywności i skuteczności. Jeśli skupić się na wykładni prakseologicznej, można zauważyć ich wspólny rdzeń, jednakże pierwsze z pojęć odnosi się do nakładów, a drugie do celu (Kulikowska-Pawlak, 2010, s. 65). Podobnie jest z produktywnością jako terminem stosowanym zamiennie z pojęciem efektywności. Produktywność jest stosunkiem przynoszących wartość produktów do czynników biorących udział w procesie produkcji (Jacobs i in., 2013, s. 20). Tak rozumiana efektywność nie może być stosowana w ochronie zdrowia, ponieważ w przypadku szpitali wysokospecjalistycznych, gdzie przypadki są bardziej skomplikowane, nieraz beznadziejne, udaje się przeprowadzić całą procedurę prawidłowo, jednakże pacjent umiera. Umieralność podczas zabiegów/operacji jest jednym ze stosowanych wskaźników w celu oceny szpitala. W zasadzie powyższe wskazuje, iż nie można porównać efektywności szpitali o różnych profilach. W literaturze związanej stricte z ekonomią efektywność definiuje się ogólnie jako sposób używania zasobów przyczyniający się do uzyskania najwyższego poziomu satysfakcji, jaki jest możliwy przy danych nakładach i technologii (Samuelson, Nordhaus, 2012, s. 618). W niniejszym wywodzie nie sposób ominąć ważnej kwestii związanej z wieloaspektowością pojęcia definicji efektywność i koniecznością dopasowania każdorazowo definicji do sektora i sytuacji (Bielski, 2002, s. 63), tak więc rozróżnić można definicje wskazujące na 
silną rolę skuteczności w osiąganiu efektywności lub efektywność jako kryterium oceny skuteczności, inne z kolei podkreślają niezależność skuteczności i efektywności. W literaturze przedmiotu pojawiają się również takie, które wprost określają efektywność jako produktywność lub wydajność, istnieją też określenia efektywności odnoszące się do alokacji zasobów w sensie zasady Pareto (Łęgowski, 2018, s. 98). Podobnie J. Gerlach i M. Gil (2018, s. 14) prezentują przegląd definicji, rozróżniając je przy zastosowaniu pojęć skuteczności, produktywności, wydajności czy alokacji zasobów. Efektywność można również interpretować przez celowość (porównanie wyników do założonych celów, skupia się głównie na budżetowaniu), systemowość (podejście od strony zasobów systemu, a konkretniej ich pozyskiwania - pomijane jest wykorzystanie zasobów) i od strony interesariuszy (spełnienie oczekiwań interesariuszy zewnętrznych i wewnętrznych - wybór na podstawie sily interesariuszy) (Bratnicki, Kulikowska-Pawlak, 2013, s. 59). Innym podziałem efektywności jest podział na efektywność organizacyjną i ekonomiczną (Głodziński, 2014, s. 157), definiując efektywność jako osiągane rezultaty vs. wykorzystane nakłady. Efektywność ekonomiczną należy rozumieć jako relację wyników do kosztów ich osiągania, natomiast efektywność organizacyjna to szerokie zagadnienie odnoszące się do pozytywnych wyników i atrybutów przedsiębiorstwa. Efektywność finansowa jest poruszana $w$ naukach o finansach i ekonomii, natomiast organizacyjna w naukach o zarządzaniu i jakości (Ziębicki, 2012, s. 381). Ciekawą definicję efektywności zaproponowała M. Kulikowska-Pawlak (2010, s. 81), która traktuje efektywność jako ilościową cechę pewnego działania odzwierciedloną w relacji efektów użytkowych, które osiąga się $\mathrm{w}$ danym okresie, dążących do zapewnienia potrzeb odbiorców oraz zasobów niezbędnych do uzyskania efektów. Kolejna definicja efektywności odnosi się do racjonalności, uznając efektywność jako kluczowy czynnik gospodarowania dążącego do optymalnego zaspokajania potrzeb przy ograniczonych zasobach (Jaki, 2011, s. 3). Efektywność określa się również jako zdolność do osiągania celów i realizacji strategii, co jest zależne od wykonywania rzeczy we właściwy sposób (Skrzypek, 2012, s. 315). Ochrona zdrowia również doczekała się swojej definicji efektywności S. Poździocha z 2000 r. mówiącej, iż efektywność jest to zespół zorganizowanych i skoordynowanych działań, którego celem jest udzielanie świadczeń, usług profilaktyczno-leczniczych oraz rehabilitacyjnych, które mają na celu zabezpieczenie i poprawę zdrowia pacjenta i społeczności (Kautsch, 2011, s. 63). Efektywność w ochronie zdrowia jest możliwością oceny rezultatu usług medycznych. Jednostki pomiaru tak rozumianej efektywności sięgają aspektów finansowych i niefinansowych (Saryusz-Wolska, Wronka, 2013, s. 257). Autorka przychyla się definicji z 2000 r. jako wiodącej i najlepiej oddającej istotę, jednak skłania się do jej uzupełnienia o część medyczną, czyli efekt zdrowotny. Efektywność $\mathrm{w}$ ochronie zdrowia jest zespołem skoordynowanych działań na różnych szczeblach referencyjności przynoszących poprawę zdrowia pacjentów poprzez świadczenie usług medycznych i profilaktykę.
Mnogość definicji i zależności ich składników powoduje konieczność każdorazowego doprecyzowania znaczenia pojęcia. Skoro w języku polskim jest tyle wątpliwości co do znaczenia efektywności, warto odwołać się do angielskiego słownictwa. Efektywność ekonomiczną tłumaczy się jako economic effectiveness, natomiast efektywnie - effectively, efficiently zaś oznacza efektywnie w sensie wydajnie (Oxford Stownik, 2008, s. 142). W związku z tym najwłaściwszym tłumaczeniem dla efektywności opisywanej w niniejszym artykule powinno być effectiveness. Literatura odwołuje się często do pozafinansowych aspektów efektywności, np. efektywności organizacyjnej, efektywności zarządczej czy wpływu jakości na efektywność, co pokazuje pewne zaniedbane obszary w literaturze polskiej, ujawniając lukę badawczą.

Najczęściej efektywność w ochronie zdrowia w badaniach polskich jest ujmowana jako rezultat wprowadzanych zmian bądź badanych zależności. Przykłady takich prac dotyczą zasobów ludzkich (Buchelt, 2017), orientacji przedsiębiorczej/przedsiębiorczości (Głód, 2016), zarządzania publicznego (Frączkiewicz-Wronka, 2010) czy przywództwa (Austen, 2010). W literaturze analizowane są również takie kwestie jak wpływ komercjalizacji na efektywność czy powiązanie wyników finansowych z efektywnością. Literatura dotycząca efektywności dzieli się na efektywność podmiotów i sektora, prezentując koncepcje badawcze wskaźnikowe, parametryczne i nieparametryczne, w praktyce oparte na macierzach, karcie wyników, wskaźnikach finansowych oraz metodzie DEA. Na podstawie przeglądu literatury można zidentyfikować również artykuły porównujące efektywność systemów np. w krajach OECD lub Unii Europejskiej. Podczas badań warto zwrócić uwagę na serię raportów OECD Health at a Glance przedstawiających wybrane (kluczowe dla efektywności systemu) dane. Nie bez znaczenia są jednak artykuły teoretyczne (Bratnicki, Frączkiewicz-Wronka, 2006; Dubas, 2011; Niemczyk, 2014; Nojszewska, 2011), będące bazą wiedzy o podziale efektywności czy zależności między poziomami.

Można analizować efektywności ochrony zdrowia jako systemu, efektywności w skali mikro (czyli podmiotu), a także $\mathrm{w}$ poszczególnych przypadkach medycznych i próbować mierzyć efektywność leczenia. W przypadku sektora ochrony zdrowia efektywności na poszczególnych poziomach są od siebie zależne. Nie można mówić, że placówka medyczna jest efektywna, jeśli nie ma efektywności leczenia pacjentów. Natomiast efektywność systemu zależy bezpośrednio od efektywności podmiotów leczniczych, które w dużej mierze są finansowane systemowo. Według najnowszego raportu GUS, w 2016 r. aż 96,5\% hospitalizacji w Polsce odbywało się w ramach finansowania NFZ (GUS, 2018, s. 42), co stanowi porównywalną wartość do roku 2013 - 97,6\% (GUS, 2015, s. 42). W związku z tym można założyć, iż ochrona zdrowia jest systemem naczyń połączonych i każdy poziom musi przynosić pozytywne wyniki, żeby całość była sprawna. Warto jednak podkreślić, iż suma efektywności podmiotów leczniczych nie jest równa efektywności systemu ochrony zdrowia (Rudawska, 2011, s. 141). Tabela 1 prezentuje poziomy efektywności ochrony zdrowia. 
Tabela 1. Poziomy efektywności w ochronie zdrowia

\begin{tabular}{|l|l|l|l|}
\hline \multicolumn{1}{|c|}{$\begin{array}{c}\text { Poziom } \\
\text { efektywności }\end{array}$} & \multicolumn{1}{|c|}{ Makro } & \multicolumn{1}{c|}{ Mikro } & \multicolumn{1}{c|}{ Przypadek medyczny } \\
\hline Cel & $\begin{array}{l}\text { Zapewnienie funkcjonowania } \\
\text { systemu ochrony zdrowia }\end{array}$ & $\begin{array}{l}\text { Utrzymanie pozytywnej sytuacji } \\
\text { finansowej oraz dobrej reputacji }\end{array}$ & $\begin{array}{l}\text { Uzyskanie maksymalnego efektu } \\
\text { zdrowotnego, poprawa zdrowia pacjenta }\end{array}$ \\
\hline Interesariusze & Politycy, społeczeństwo & $\begin{array}{l}\text { Akcjonariusze, właściciele, } \\
\text { zarządzający podmiotem }\end{array}$ & $\begin{array}{l}\text { Pacjenci, personel medyczny, w umiarkowany } \\
\text { sposób kadra zarządzająca }\end{array}$ \\
\hline
\end{tabular}

Źródło: opracowanie własne

Na poszczególnych poziomach efektywności można zidentyfikować bariery wpływające na efektywność. Wspomniane już silne zależności między systemem a sektorem powodują, iż bariery kwalifikowane do poziomu makro wpływają na poziom mikro oraz poziom przypadku medycznego. Ich znajomość pozwala na podejmowanie działań przeciwstawnych lub zidentyfikowanie wysiłków w celu podwyższenia efektywności wbrew barierom.

\section{Główne bariery efektowności ochrony zdrowia}

G łówne problemy ochrony zdrowia można zidentyfikować na poziomie makro. Są to bariery strukturalne utrudniające sprawne zarządzanie podmiotami leczniczymi. Podstawowym problemem jest brak personelu medycznego oraz starzenie się kadry. Aktualnie lekarzy w Polsce mamy 2,4 na 1000 mieszkańców, co stanowi jeden z gorszych wyników w krajach OECD (2019, s. 179). Dodatkowo nie bez znaczenia jest wiek przeciętnego lekarza posiadającego specjalizację, wynosił on w 2015 r. 54,5 lat (Krajewski, 2015, s. 5). Dodatkowo przez konieczność informatyzacji podmiotów leczniczych (Rozporządzenie MZ, 2015) starsi lekarze emeryci, których kontakt z komputerem zwykle był ograniczony do niezbędnego minimum, są zmuszeni do rezygnacji z czynnego wykonywania zawodu, aby uniknąć konieczności korzystania $\mathrm{z}$ infrastruktury informatycznej.

Dodatkowo warto zwrócić uwagę na nierówności w rozmieszczeniu personelu lekarskiego na mapie Polski (Kautsch, 2011, s. 65). Lekarze często pozostają w ośrodkach akademickich, co powoduje ciężką sytuację w szpitalach regionalnych. Lekarze nie są jedyną grupą zawodową, której brakuje, ponieważ podobnie wypadają na tle innych krajów pielęgniarki (OECD, 2019, s. 182). Ciekawym zjawiskiem jest również brak fizjoterapeutów. Jeszcze kilka lat temu liczba dostępnych na rynku profesjonalistów przewyższała popyt. Aktualnie przykładowo w województwie śląskim są zawodem deficytowym (Wojewódzki Urząd Pracy w Katowicach, 2018, s. 18). Bariera braku dostępności personelu odbija się na podmiotach leczniczych, po pierwsze z powodu braku pracowników do świadczenia usług (szczególnie problematyczne podczas współpracy z NFZ), a po drugie ze względu na stawki, jakie należy płacić personelowi.

W związku z działaniami projakościowymi poszczególnych grup specjalistów zwiększającymi jakość i bezpieczeń- stwo pacjentów również wymagania co do liczby personelu podczas dyżurów rośnie (Rozporządzenie MZ, 2016). Niesie to pozytywny skutek dla opieki nad pacjentem, jednak utrudnia sytuację na i tak trudnym rynku pracownika, gdzie budowanie marki pracodawcy przez niedobory środków jest wyzwaniem. Dzięki rynkowi pracownika stawki, które mogą otrzymać profesjonaliści medyczni, są często wyższe niż wynika to $\mathrm{z}$ wyceny świadczeń medycznych. Za prawidłową wycenę świadczeń odpowiada Agencja Oceny Technologii Medycznych i Taryfikacji oraz NFZ pełniący funkcję płatnika. Niestety, wycena świadczeń medycznych odbiega od stawek komercyjnych. Brak prawidłowej wyceny świadczeń i brak waloryzacji ceny za punkt jest problemem wielu podmiotów medycznych. Przykładowo w ambulatoryjnej opiece specjalistycznej dochodzi czasem do sytuacji, gdzie ceny komercyjne są dwukrotnie wyższe niż stawki proponowane przez NFZ za świadczenie'. W innej sytuacji jest publiczny podmiot, np. szpital w formie Samodzielnego Publicznego Zakładu Opieki Zdrowotnej, który w przeciwieństwie do podmiotów prywatnych nie może świadczyć usług komercyjnych. Dodatkowo na nieciekawą sytuację tej grupy jednostek ochrony zdrowia wpływają nieopłacalne procedury/zabiegi. Koszt niektórych procedur przewyższa stawkę otrzymywaną od NFZ za wykonanie świadczenia. Dodatkowo pogorszenie sytuacji zwiastują zmiany związane z odpadami medycznymi (wprowadzenie systemu BDO) i podwyżki cen prądu.

Kolejną barierą jest niewykorzystanie efektów skali (Morris i in., 2011, s. 91). Podmioty lecznicze często nie wykorzystują swoich możliwości, głównie sprzętowych. Zdarza się tak, że mimo posiadania wysokiej klasy sprzętu diagnostycznego jest on wykorzystywany raz na kilka dni. Przykładem były tomografy ograniczone limitem punktów. Po zniesieniu limitu w wielu jednostkach uwydatnił się problem $\mathrm{z}$ brakiem personelu niezbędnego do opisu lub wykonania badania. Również limity świadczeń przekładają się na nieefektywność podmiotów leczniczych. Przykładowo jeśli podmiot $\mathrm{w}$ procedurze konkursu ofert wykazał 4 fizjoterapeutów w ramach pełnego etatu, a uzyskał kontrakt o wartości uniemożliwiającej choćby pokrycie pensji pracowników, musi albo dokładać środki, albo nie podpisać umowy na zaproponowanych warunkach (OWU, 2015). Możliwa jest renegocjacja umowy w zakresie zgodnym z uzyskaną punktacją konkursową. Powyższe przykłady są dużym marnotrawstwem zasobów będącym jednym z problemów ochrony zdrowia (Raczyńska, 2016, s. 687). Kolejną barierą dla efektywności podmiotów leczniczych 
jest upolitycznienie sektora, a przez to ciągłe zmiany systemu i zasad jego funkcjonowania, co ciągnie za sobą niepewność utrudniającą podejmowanie decyzji. Brak konkursów ofert uniemożliwia otwarcie się nowych, dużych, nowoczesnych podmiotów gotowych na współpracę z narodowym płatnikiem. Również rozbudowana biurokracja jest barierą dla efektywności, skomplikowany system kolejkowy nie zawsze jest zgodny z realnymi czasami przyjęć. Potencjalnych barier efektywności w podmiocie leczniczym jest bardzo dużo, a cały sektor ochrony zdrowia to system naczyń połączonych uzależniających jeden poziom efektywności od drugiego. Znajomość determinant efektywności bez wątpienia ułatwia zarządzanie i wskazuje miejsce usprawnień w organizacji, a podział analizowanych danych na wymiary ułatwi kontrolę nad podmiotem leczniczym oraz próbę porównań benchmarkingowych.

\section{Determinanty efektywności}

I iteratura polska jest bardzo specyficzna, jeśli chodzi ـ o badanie efektywności. Efektywność jest tu badana, w kontraście do literatury światowej, najczęściej przez pryzmat wyników finansowych (lub pomiar dokonywany jest wskaźnikami finansowymi). Ciekawe badania były związane z przekształceniami Samodzielnych Publicznych Zakładów Opieki Zdrowotnej w spółki prawa handlowego zgodnie z ustawą o działalności leczniczej nakazującej zmianę formy prawnej szpitala $\mathrm{w}$ formie SPZOZ, jeżeli przyniósł on stratę, a organ założycielski nie chce pokryć ujemnego wyniku finansowego (Horosz, 2011, s. 26). Zapewne bardzo ciekawe są pojedyncze studia przypadków, gdzie przekształcenie rzeczywiście przyniosło pozytywne zmiany (Łagowski, 2018, s. 108), jednakże w większości nie poprawiło to sytuacji podmiotów (Kujawska, 2016, s. 238). Problemy z mierzeniem efektywności opierają się często na błędnym założeniu, że liczy się wyłącznie wynik i wskaźniki finansowe. Powszechnie stosowane w celu oceny efektywności poszczególnych oddziałów są np. wskaźniki związane z obłożeniem łóżek, przelotowości łóżek szpitalnych, wskaźnik umieralności czy czas trwania operacji porównywane na zasadzie benchmarkingu lub oparte na badaniach naukowych. Zdaniem K. Dubas, należy się opierać na matrycy wielokryterialnej oceny efektywności funkcjonowania zakładu opieki zdrowotnej,

Tabela 2. Matryca pomiaru

\begin{tabular}{|c|c|c|}
\hline Wymiar efektywności & Czego dotyczy & Działania zwiększające efektywność \\
\hline Wymiar finansowy & $\begin{array}{l}\text { Skupia się na kwestiach związanych } \\
\text { z finansami, obejmuje głównie wskaźniki } \\
\text { płynności, sprawności działania, poziomu } \\
\text { zadłużenia czy rentowności. Kryterium } \\
\text { łatwe do zbadania. }\end{array}$ & $\begin{array}{l}\text { - Kontrola stanu rozliczenia świadczeń (w celu uzyskania płatności za } \\
\text { ewentualne nadwykonania); } \\
\text { - Regularna kontrola wskaźników finansowych; } \\
\text { - Prowadzenie rachunku kosztów i polityki rachunkowości zarządczej. }\end{array}$ \\
\hline Wymiar techniczny & $\begin{array}{l}\text { Jest związany ze wszystkimi zasobami } \\
\text { szpitala, operuje wskaźnikami, } \\
\text { np. wskaźnik obłożenia łóżek, można } \\
\text { wykorzystywać własne wskaźniki. }\end{array}$ & $\begin{array}{l}\text { - Prowadzenie polityki daty użytkowania sprzętu medycznego; } \\
\text { - Kontrola poziomu obłożenia łóżek i porównywanie ich z innymi } \\
\text { oddziałami wewnątrz podmiotu; } \\
\text { - Stosowanie nowoczesnych koncepcji zarządzania typu lean } \\
\text { management, 5S, Kaizen, Kaban. }\end{array}$ \\
\hline Wymiar jakościowy & $\begin{array}{l}\text { Obejmuje jakość usług medycznych } \\
\text { oraz jakość gwarantowaną certyfikatami } \\
\text { (punktowanymi w procedurze } \\
\text { konkursowej lub nie). Jednakże można } \\
\text { także odnieść do satysfakcji pacjenta, } \\
\text { ilości skarg zewnętrznych do sądu lub } \\
\text { komisji, ilości zdarzeń niepożądanych lub } \\
\text { kwestii związanych ze spójnością norm } \\
\text { i systemów. }\end{array}$ & $\begin{array}{l}\text { - Uzyskanie certyfikatów, szczególnie akredytacyjnego; } \\
\text { - Próba integracji norm ISO; } \\
\text { - Spójność procedur jakościowych podlegających różnym systemom/ } \\
\text { normom/narzędziom; } \\
\text { - Stworzenie mechanizmów reakcji na obniżenie jakości. }\end{array}$ \\
\hline Wymiar behawioralny & $\begin{array}{l}\text { Jest związany z motywacją pracowników, } \\
\text { skupia się na wszelkich aspektach } \\
\text { dotyczących wynagrodzeń, zadowolenia } \\
\text { pracowników, szkoleń, motywacji } \\
\text { pozafinansowej, atmosfery i podejścia do } \\
\text { pracowników. } \\
\text { Łączy się z budowaniem marki } \\
\text { pracodawcy (Buchelt, Frączkiewicz- } \\
\text {-Wronka, 2017, s. 94). }\end{array}$ & $\begin{array}{l}\text { - Przywiązanie pracowników aspektami pozafinansowymi do } \\
\text { jednostki; } \\
\text { - Dbanie o rozwój pracowników, dofinansowywanie (lub uzyskiwanie } \\
\text { w ramach Krajowego Funduszu Szkoleniowego lub Bazy Usług } \\
\text { Rozwojowych; } \\
\text { - Umożliwienie zapewnienia pracownikom równowagi między życiem } \\
\text { zawodowym a prywatnym; } \\
\text { - Dbanie o stronę wizerunkową jednostki w celu przyciągnięcia } \\
\text { potencjalnych pracowników. }\end{array}$ \\
\hline Wymiar rozwojowy & $\begin{array}{l}\text { Dotyczy przede wszystkim planów } \\
\text { rozwojowych organizacji oraz } \\
\text { pozyskiwania na ten cel funduszy, ważna } \\
\text { jest tu też wizja podmiotu leczniczego } \\
\text { i możliwości uzyskiwania kontraktów na } \\
\text { kolejne zakresy świadczeń. }\end{array}$ & $\begin{array}{l}\text { - Tworzenie długoterminowych strategii rozwoju; } \\
\text { - Tworzenie planów działania na wypadek przegrania konkursu ofert; } \\
\text { - Śledzenie możliwości inwestycyjnych w ramach dofinansowań z UE } \\
\text { lub MZ; } \\
\text { - Rozwój placówek w zależności od dostępnych zasobów personalnych } \\
\text { na danym rynku (dotyczy mniejszych podmiotów). }\end{array}$ \\
\hline
\end{tabular}

Źródto: opracowanie własne na podstawie: Dubas, 2011, s. 112 
Tabela 3. Matryca w podmiocie leczniczym

\begin{tabular}{|l|l|l|}
\hline $\begin{array}{c}\text { Wymiar } \\
\text { efektywności }\end{array}$ & \multicolumn{1}{|c|}{ Potencjalny problem } & \multicolumn{1}{c|}{ Potencjalne rozwiązanie } \\
\hline Wymiar finansowy & Ujemny, wynik finansowy & $\begin{array}{l}\text { Pokrycie straty przez organ założycielski i identyfikacja źródeł największych kosztów, } \\
\text { kolejno benchmarking z innymi podmiotami leczniczymi. }\end{array}$ \\
\hline Wymiar techniczny & $\begin{array}{l}\text { Zbyt niskie wykorzystanie sprzętu } \\
\text { medycznego }\end{array}$ & $\begin{array}{l}\text { Wykonywanie większej ilości badań, podłączenie sprzętu w wyznaczonych godzinach } \\
\text { do innej komórki organizacyjnej, wykonywanie badań komercyjnych lub w ramach } \\
\text { podwykonawstwa. }\end{array}$ \\
\hline Wymiar jakościowy & $\begin{array}{l}\text { Duży odsetek niezadowolonych } \\
\text { pacjentów }\end{array}$ & $\begin{array}{l}\text { Przeprowadzenie dokładnej ankiety satysfakcji pacjenta zgodnie z procesem } \\
\text { przepływu pacjenta w danym podmiocie, przeszkolenie pracowników w zakresie } \\
\text { obsługi pacjenta, wychwycenie punktów krytycznych. }\end{array}$ \\
\hline Wymiar behawioralny & Brak personelu do pracy & $\begin{array}{l}\text { Wprowadzenie wizerunku przyjaznego pracodawcy poprzez prowadzenie mediów } \\
\text { społecznościowych, umożliwienie pracownikom rozwoju zawodowego. }\end{array}$ \\
\hline Wymiar rozwojowy & Brak pieniędzy na informatyzację & Skorzystanie z dotacji MZ za pośrednictwem NFZ, skorzystanie ze środków unijnych. \\
\hline
\end{tabular}

Źródło: opracowanie własne

Tabela 4. Rekomendacje dla nauki i praktyki

\begin{tabular}{|c|c|}
\hline Rekomendacje dla nauki & Rekomendacje dla praktyki \\
\hline $\begin{array}{l}\text { - badania w zakresie wpływu poszczególnych wymiarów } \\
\text { efektywności na wyniki organizacji (również pozafinansowe); } \\
\text { - badanie możliwości wykorzystania nowoczesnych narzędzi } \\
\text { zarządzania w podmiotach ochrony zdrowia na poszczególnych } \\
\text { poziomach referencyjności; } \\
\text { - badanie możliwości integracji komórek organizacyjnych w celu } \\
\text { zwiększenia efektywności systemu zarządzania. }\end{array}$ & $\begin{array}{l}\text { - poszukiwanie zwiększenia efektywności w nowoczesnym zarządzaniu } \\
\text { z wykorzystaniem Lean Management, benchmarkingu, zarządzania } \\
\text { turkusowego; } \\
\text { - wzmocnienie pozafinansowej motywacji pracowników poprzez } \\
\text { budowanie marki pracodawcy; } \\
\text { - inwestowanie w wysoką jakość w celu podniesienia efektywności } \\
\text { podmiotu; } \\
\text { - korzystanie ze środków poza NFZ (jeśli jest to dopuszczalne) w celu } \\
\text { wykorzystania efektu skali; } \\
\text { - zwracanie większej uwagi na zbierane dane i analizowanie ich na } \\
\text { potrzeby zarządcze. }\end{array}$ \\
\hline
\end{tabular}

Źródło: opracowanie wtasne

która obejmuje więcej czynników niezbędnych w turbulentnym otoczeniu. Matryca wskazuje następujące wymiary: finansowy, techniczny, jakościowy, behawioralny i rozwojowy. Tabela 2 opiera się na matrycy przedstawiającej, czego dotyczą wymiary oraz jakie można wykorzystać elementy celem zwiększenia efektywności danych wymiarów. Natomiast tabela 3 prezentuje przykładowe problemy i rozwiązania w wybranych wymiarach.

Niestety, jak wynika z badań (Lisiecka, Czyż-Gwiazda, 2017, s. 147), zarządzający podmiotami leczniczymi nie wykorzystują miar efektywności pozafinansowej w swojej działalności menedżerskiej. Co ciekawe, część tych danych jest obligatoryjnie zbierana do sprawozdań kierowanych do instytucji publicznych, jednak zwykle nie są analizowane wewnątrz organizacji. $\mathrm{Na}$ tej podstawie można wnioskować o małej świadomości zarządzających podmiotami leczniczymi o wpływie np. czynników technicznych na efektywność i wyniki organizacji.

\section{Wnioski dla nauki i praktyki}

D odstawowym wnioskiem dla nauki i praktyki jest podkreślenie ważności efektywności i wskazania ich barier, gdzie efektywność w różnych skalach wpływa na siebie. Rynek pracownika w sektorze ochrony zdrowia jest wyjątkowo trudny, dlatego też należy stosować motywację finansową, ale również pozafinansową. Efektywność to nie tylko finanse, warto więc $\mathrm{w}$ badaniach skupić się na pozafinansowych czynnikach wpływających na efektywność podmiotu leczniczego - wyeksponować takie elementy, jak: jakość (nawet jeśli nie istnieje w podmiotach wystarczająca motywacja do certyfikacji), wysoką obsługe klienta czy czynniki behawioralne. Rekomendacji może być wiele, jednakże najważniejsze zostały ujęte w tabeli 4 .

Najważniejszy wniosek wysuwający się z powyższych rozważań dla praktyki i nauki to konieczność nowoczesnego spojrzenia na sektor ochrony zdrowia oraz skupienie się na stronie organizacyjnej. Oprócz zwiększenia wydatków na system ochrony zdrowia, ważne jest również zidentyfikowanie na poszczególnych poziomach sektora wzorców efektywności uwzględniających dyscyplinę medyczną (zakresy np. opieki psychiatrycznej i leczenia uzależnień). Literatura przedmiotu pokazuje wykorzystanie metod zarządzania w ochronie zdrowia, implementując poszczególne założenia, np. traktując lean management jako lean hospitals (Graban, 2011). Efektywność często jest traktowana jako „wynik” działania i sposób pomiaru zmian wprowadzonych do organizacji. Patrząc na efektywność jako cel, powinno się kształtować działania zwiększające wszystkie wymiary efektywności (tab. 2). 


\section{Podsumowanie}

0 chrona zdrowia znajduje się $\mathrm{w}$ trudnej sytuacji, gdzie nacisk na efektywność maleje. Latami była wynagradzana nieefektywność $\mathrm{w}$ postaci oddłużania jednostek. Niestety nawet w sytuacji, gdy pojawiła się presja, skupiono się głównie na wynikach finansowych, co nie zawsze miało pozytywne skutki. Bariery efektywności są dużym problemem ochrony zdrowia w Polsce, zależnym od wielu czynników. Aktualnie podmioty chcące zyskać przewagę konkurencyjną muszą stosować strategie zgodne $\mathrm{z}$ trendami, ponieważ publiczny sektor ochrony zdrowia staje ciągle naprzeciw trudnościom i wyzwaniom. Należy doskonalić badania nad efektownością i opracować spójne systemy mogące pomóc podmiotom leczniczym być prawidłowo zarządzanymi w trudnym otoczeniu. Nie bez znaczenia będzie działalność władz w celu likwidacji barier efektywności w skali makro. Póki sytuacja nie ulegnie poprawie zarządzający będą zmuszeni stosować koncepcje zarządzania mające na celu pozyskanie kadry specjalistów i utrzymanie ich oraz wiodącej pozycji konkurencyjnej. Dalsze kierunki badawcze powinny być odpowiedzią na wymagania sektora. Kwestie związane ze zwiększeniem efektywności, to m.in. wpływ integracji systemów zarządzania jakością czy wpływ zastosowania nowoczesnych koncepcji zarządzania na efektywność organizacyjną. Aktualne działania proefektywnościowe makroekonomiczne można zauważyć we wzorze na ryczałt szpitali, a także w działaniach Agencji Oceny Technologii Medycznych i Taryfikacji, czy też w próbie wdrożenia jednolitego systemu rachunkowości pozwalającego na benchmarking jednostek ochrony zdrowia o podobnych profilach.

\section{mgr Ewa Raczyńska \\ Uniwersytet Ekonomiczny w Katowicach \\ Kolegium Ekonomii \\ ORCID: 0000-0002-7834-1353 \\ e-mail: ewa.raczynska@uekat.pl}

\section{Przypis}

1) Opracowanie własne na potrzeby artykułu polegające na obliczeniu wynagrodzenia za wykonaną procedurę $\mathrm{w}$ ramach umowy NFZ dla wybranego podmiotu leczniczego i porównanie z cennikiem usług komercyjnych.

\section{Bibliografia}

[1] Austen A. (2010), Efektywność przywództwa w organizacji publicznej, „Organizacja i Zarządzanie. Kwartalnik Naukowy”, Nr 4(12), s. 25-41.

[2] Bielski M. (2002), Podstawy teorii organizacji i zarzadzania, Wyd. C.H. Beck, Warszawa.

[3] Bratnicki M., Kulikowska-Pawlak M. (2013), Uwarunkowania pomiaru efektywności organizacji, „Finanse i Zarządzanie", T. 4, Nr 2, s. 53-66.
[4] Bratnicki M., Frączkiewicz-Wronka A. (2006), Efektywność organizacyjna i zarzadzanie publiczne - wyłaniajace się koncepcje, kluczowe wyzwania i kierunki dalszych badań w obszarze pomiaru efektywności, „Organizacja i Kierowanie", Nr 3, s. 17-32.

[5] Buchelt B. (2017), Koncepcja systemu zarzadzania efektywnościa pracy personelu medycznego w szpitalach, Zeszyty Naukowe Uniwersytet Ekonomiczny w Krakowie. Seria Specjalna, Monografie.

[6] Buchelt B., Frączkiewicz-Wronka A. (2017), Identyfikacja czynników decydujących o atrakcyjności szpitala powiatowego jako pracodawcy, „Management Sciences”, $\mathrm{Nr}$ 3(32), s. 93-101.

[7] Dubas K. (2011), Problematyka efektywności w ochronie zdrowia - znaczenie i metody pomiaru, „Problemy Zarządzania”, T. 9, Nr 3(33), s. 102-125.

[8] Frączkiewicz-Wronka A. (2010), Pomiar efektywności organizacji jako obszar konwergencji metod, narzędzi i instrumentów zarządzania między sektorami biznesowym a publicznym, „Organizacja i Zarządzanie. Kwartalnik Naukowy”, Nr 4(12), s. 5-24.

[9] Gerlach J., Gil M. (2018), Efektywność przedsiębiorstwa $w$ teorii ekonomii - która $z$ definicji najlepiej oddaje istotę zagadnienia? „Współczesne Problemy Ekonomiczne”, Nr 2/18, s. 13-22.

[10] Gierszewska G., Romanowska M. (2017), Analiza strategiczna przedsiębiorstwa, Polskie Wydawnictwo Ekonomiczne, Warszawa.

[11] Głodziński E. (2014), Efektywność ekonomiczna - dylematy definiowania i pomiaru, Zeszyty Naukowe Politechniki Śląskiej, Seria: Organizacja i Zarządzanie, Nr 73, s. $155-167$.

[12] Głód G. (2016), Uwarunkowania i pomiar przedsiębiorczości publicznej w jednostkach ochrony zdrowia, Difin, Warszawa.

[13] Graban M. (2011), Lean Hospitals - Doskonalenie szpitali. Poprawa jakości, bezpieczeństwo pacjentów i satysfakcja personelu, ProdPublishing, Wrocław.

[14] GUS (2015), Ochrona zdrowia $w$ gospodarstwach domowych w 2013 r., https://stat.gov.pl/obszary-tematyczne/zdrowie/zdrowie/ochrona-zdrowia-w-gospodarstwach-domowych-w-2013-r-,2,5.html, data dostępu 22.12.2019 r.

[15] GUS (2018), Ochrona zdrowia $w$ gospodarstwach domowych w 2016 r., https://stat.gov.pl/obszary-tematyczne/zdrowie/zdrowie/ochrona-zdrowia-w-gospodarstwach-domowych-w-2016-r-,2,6.html, data dostępu 22.12.2019 r.

[16] Horosz P. (2011), Komercjalizacja szpitali i jej skutki $w$ świetle przepisów polskiego prawa gospodarczego, ABC Wolters Kluwers business, Warszawa.

[17] Jacobs R., Smith P.C., Street A. (2013), Mierzenie efektywności w ochronie zdrowia, ABC Wolters Kluwer business, Warszawa.

[18] Jaki A. (2011), Paradygmat efektywności w zarządzaniu, „Przegląd Organizacji”, Nr 4, s. 3-7.

[19] Kautsch M. (2011), Cele systemu ochrony zdrowia a efektywność w ochronie zdrowia w Polsce, „Problemy Zarządzania", T. 9, Nr 3, s. 62-78. 
[20] Kolasa K. (2012), Optymalna alokacja zasobów w ochronie zdrowia, ABC Wolters Kluwer business, Warszawa.

[21] Konstytucja Rzeczpospolitej Polskie z dnia 2 kwietnia 1997 r., Dz.U. 1997, Nr 78, poz. 483.

[22] Krajewski R. (2015), Lekarze specjaliści i lekarze dentyści specjaliści 2015, https://www.nil.org.pl/__data/assets/ pdf_file/0005/99743/Demografia-lekarze-specjalisci-2015-v-0423.pdf, data dostępu: 13.12.2019 r.

[23] Kujawska J. (2016), Koncepcja pomiaru efektywności podmiotu leczniczego, Prace Naukowe Uniwersytetu Ekonomicznego we Wrocławiu, $\mathrm{Nr} 442$, s. 230-239.

[24] Kulikowska-Pawlak M. (2010), Pojmowanie efektywności organizacji - definiowanie, pomiar, [w:] A. Frączkiewicz-Wronka (red.), Pomiar efektywności organizacji publicznych na przykładzie sektora ochrony zdrowia, Prace Naukowe Akademii Ekonomicznej im. Karola Adamieckiego w Katowicach, Katowice, s. 63-99.

[25] Lisiecka K., Czyż-Gwiazda E. (2017), System pomiaru wyników organizacyjnych w podmiotach leczniczych. Wyniki badań pilotażowych, Studia Ekonomiczne. Zeszyty Naukowe Uniwersytetu Ekonomicznego w Katowicach, Nr 321, s. 136-152.

[26] Łagowski P. (2018), Ocena efektywności świadczenia ustug medycznych przez jednostki szpitalne $z$ uwzględnieniem formy organizacyjno-prawnej podmiotu, „Studia i Prace Kolegium Zarządzania i Finansów”, Nr 167, s. 95-110.

[27] Morris S., Devlin N., Parkin D. (2011), Ekonomia w ochronie zdrowia, Wolters Kluwers, Warszawa.

[28] Niemczyk M. (2014), Współczesne metody pomiaru efektywności funkcjonowania systemów zdrowotnych, „Studia Ekonomiczne", Nr 180, Cz. 2, s. 185-197.

[29] Nojszewska E. (2011), Efektywność ekonomiczna jako narzędzie analityczne dla ochrony zdrowia, „Problemy Zarządzania", T. 9, Nr 3, s. 11-26.

[30] Nojszewska E., Sielska A., Gołąb-Bełtowicz D. (2019), Raport z badania sytuacji finansowej szpitali powiatowych - Szklarska Poręba'19, https://www.zpp.pl/storage/files/ 2019-09//5f7be826344f9b0e809addee4d2fd2eb6131.pdf, data dostępu: 5.12.2019 r.

[31] OECD (2019), Health at a Glance: Europe 2018 State Of Health In The Eu Cycle, https://ec.europa.eu/health/sites/ health/files/state/docs/2018_healthatglance_rep_en.pdf, access dare: 10.12.2019.

[32] OWU (2015), Rozporządzenie Ministra Zdrowia z dnia 8 września 2015 r. w sprawie ogólnych warunków umów o udzielanie świadczeń opieki zdrowotnej, Dz.U. 2015, poz. 1400.

[33] Oxford Słownik Polsko-Angielski Polish-English Dictionary (2008), Wydawnictwo Naukowe PWN, Warszawa.

[34] Paździor A., Paździor M. (2017), Pomiar efektywności działalności podmiotów leczniczych. Wybrane aspekty, Prace Naukowe Uniwersytetu Ekonomicznego we Wrocławiu, $\mathrm{Nr} 481$, s. 54-62.

[35] Raczyńska E. (2016), Analiza możliwości implementacji koncepcji Lean Management w ochronie zdrowia, „Marketing i Rynek", Nr 7, s. 686-703.

[36] Rozporządzenie Ministra Zdrowia $\mathrm{z}$ dnia 9 listopada 2015 r. w sprawie rodzajów, zakresu i wzorów dokumen- tacji medycznej oraz sposobu jej przetwarzania, Dz.U. 2015, poz. 2069.

[37] Rozporządzenie Ministra Zdrowia z dnia 16 grudnia 2016 r. w sprawie standardu organizacyjnego opieki zdrowotnej w dziedzinie anestezjologii i intensywnej terapii, Dz.U. 2016, poz. 2218.

[38] Rudawska I. (2011), Zintegrowana opieka zdrowotna: w poszukiwaniu poprawy efektywności, „Problemy Zarządzania”, T. 9, Nr 3, s. 140-152.

[39] Sadowska E. (2016), Stużba czy ochrona, https://nipip. $\mathrm{pl} / 893-2 /$, data dostępu: 15.12.2019 r.

[40] Samuelson P.A., Nordhaus W.D. (2012), Ekonomia, Wyd. Rebis, Warszawa.

[41] Saryusz-Wolska H., Wronka M. (2013), Efektywność w opiece zdrowotnej - zarys wielowymiarowego problemu $w$ okresie transformacji, Studia Ekonomiczne. Zeszyty Naukowe Uniwersytetu Ekonomicznego w Katowicach, Nr 168, s. 256-269.

[42] Skrzypek E. (2012), Efektywność ekonomiczna jako ważny czynnik sukcesu organizacji, Prace Naukowe Uniwersytetu Ekonomicznego we Wrocławiu, Nr 262, s. 313-325.

[43] Suchecka J. (2010), Ekonomia zdrowia i opieki zdrowot$n e j$, Wolters Kluwer, Warszawa.

[44] Szymaniec-Mlicka K. (2014), Charakterystyka otoczenia organizacji publicznych, Zeszyty Naukowe Politechniki Śląskiej. Seria: Organizacja i Zarządzanie, Nr 73, s. 631-640.

[45] Wielicka K. (2014), Zarys funkcjonowania systemów opieki zdrowotnej w wybranych krajach Unii Europejskiej, Zeszyty Naukowe Politechniki Śląskiej. Seria: Organizacja i Zarządzanie, Nr 70, s. 491-504.

[46] Wojewódzki Urząd Pracy w Katowicach (2019), Barometr zawodów 2019, https://barometrzawodow.pl/userfiles/Barometr/2019/slaskie/raport_wojewodztwo_slaskie. pdf, data dostępu: 20.12.2019 r.

[47] Ziębicki B. (2012), Metodyka oceny efektywności organizacyjnej, [w:] B. Mikuła (red.), Historia i perspektywy nauk o zarzadzaniu. Ksiega pamiattkowa dla uczczenia Jubileuszu 40-lecia pracy naukowo-dydaktycznej prof. zw. dra hab. Arkadiusza Potockiego, Fundacja Uniwersytetu Ekonomicznego w Krakowie, Kraków, s. 381-391.

\section{Effectiveness in Health Care as a Challenge for Management}

\section{Summary}

Effectiveness in health care is a difficult topic as everyone could understand this issue in a different way. The paper provides an insight in the effectiveness in health care. The purpose of this paper is to present an overview of the definition of effectiveness and answer the research questions regarding determinants and barriers of effectiveness in the Polish health care system.

\section{Keywords}

effectiveness, health care, barriers 